\title{
25 Research Square \\ Cross-sectional study on Traditional pig rearing practices and cysticercosis in the southern region of Côte d'Ivoire
}

\section{Koffi Kouassi Eugène}

Institut Pasteur de Cote d'Ivoire

Soumahoro Man-Koumba

Institut Pasteur de Cote d'Ivoire

Boka 0. Marcel

Ministère de l'élevage , Abidjan

Melki Jihen

Institut Pasteur de Cote d'Ivoire

Ndri Borel

Institut Pasteur de Cote d'Ivoire

Mireille NOWAKOWSKI

Pasteur Institute: Institut Pasteur PFPR

\section{Touré O. André}

Institut Pasteur de Cote d'Ivoire

Djaman A. Joseph

Institut Pasteur de Cote d'Ivoire

N'goran K. Elieser

Universite Felix Houphouet-Boigny Unite de Formation et de Recherche Biosciences

Ronan Jambou ( $\nabla$ rjambou@pasteur.fr)

Institut Pasteur de Cote d'Ivoire https://orcid.org/0000-0002-9908-1378

\section{Research article}

Keywords: pigs, Côte d'Ivoire, cysticercosis, livestock

Posted Date: January 19th, 2021

DOI: https://doi.org/10.21203/rs.3.rs-61748/v2

License: (c) (i) This work is licensed under a Creative Commons Attribution 4.0 International License.

Read Full License 


\section{Abstract}

\section{Background}

In West Africa, pig meat, known as pork, is often supplied by traditional farms in rural districts. This practice causes significant sanitary risk because of the lack of veterinary control of farms and slaughterhouses in rural districts. This study aims to describe pig breeding practices used in southern Côte d'Ivoire to establish a surveillance system for cysticercosis disease. This survey was conducted among traditional pig producers living in villages surrounding Dabou, Aboisso, and Agboville. The data collected focused on the profile of producers and the characteristics of the farms.

Results

A total of 321 pig producers were identified (Dabou 72 (22.4\%), Aboisso 26 (8.1\%), and Agboville 223 $(69.5 \%))$. Most of the herders were male (87.8\%). The total count of animals was 3,663 heads of pigs, with mostly youngpiglets $(60.2 \%)$ and sow $(29.3 \%)$. The local race was predominant $(80.6 \%)$ for only $15.5 \%$ of half-caste races. Most of the farms used permanent divagation rearing (53.3\%). Following examination, random samples of pigs were tracked in all the selected villages using the quota methods. Animals' blood samples and serums were analyzed using Ac-ELISA and Western Blot. Out of the selected 639 animals, $13.2 \%$ had antibodies against cysticercosis with considerable variations from one village to another.

Conclusions

The study highlighted that, in these regions, pig farming remains essentially traditional, with free grazing of animals, which constitutes a significant sanitary risk, especially for Taenia solium.

\section{Background}

In 2017 , the pig livestock in Côte d'Ivoire was estimated to be 411,520 head with 80,867 modern pigs (imported breed) and 121,520 local pigs [1]. This breeding constitutes an essential source of animal protein for the Ivorian population. In addition, pig's annual national consumption reaches 105,538 tonnes, with $89 \%$ of imported products for only $11 \%$ from national production [1]. This fact highlights the market opportunities sustaining local initiatives. The national market is supplied by a great diversity of farming practices (traditional, semi-industrial, and industrial), for which data on pork food safety is missing. Further, $93 \%$ of national pig's production is not subject to official slaughter and veterinary control [1]. The southern part of Côte d'Ivoire provides most of the market for the economic capital of Abidjan. Commercial channels are very short; butchers and consumers usually acquire pork through informal transactions with villagers living in Abidjan's vicinities.

Breeds are usually local, mixed, or modern ones. Local breeds cover a wide variety of lineages with various performances. These more rustic animals are more adaptable to scare food and difficult climatic 
conditions [8], but they grow slowly and hardly reach $50 \mathrm{~kg}$ as adults. Their average daily gain (ADG) is over $400 \mathrm{~g} /$ day with a consumption index equal to 4 for weights between 20 and $60 \mathrm{~kg}$ [23]. These local breeds show large variations in the first farrowing age from one country to another, ranging from 16.5 months in Senegal [24] to 11.3 months in the Central African Republic [20]. Local breeds are diverse depending on the country: the Black Spotted and the Black Criollo with long bristles in Latin America, the Bakosi in Cameroon, and the Korhogo in Côte d'Ivoire, the Ghanaian Ashanti in Ghana, and the Windsnyer on the back sharp and Kolbrock in South Africa [8]. Their characteristics are a short forehead, an elongated snout, and small ears carried horizontally or slightly erect. A narrow-body supported by relatively long limbs with a tourniquet size ranging from 40 to 60 centimeters. The skin is black, sometimes magpie, rarely white with a silk coat more or less long and coarse [25]. Mixed-breed animals originated mostly from crossbreeds of local breeds and imported European and North American ones (Large White, Landrace, Duroc, Pietrain, Hampshire) or between local breeds and breeds of these crosses [26]. These animals are more vigorous and more resistant than those of the parental exotic breed, but with better performance than local breeds [20]. According to the Interprofessional Fund for Agricultural Research (FIRCA), in Ivorian flocks, pigs with improved zootechnical performances can also be found. These performances are $100.7 \mathrm{~kg}$ of live weight at seven months, with an average daily gain (GMQ) of $806.2 \mathrm{~g} /$ day for Large White, and $108.9 \mathrm{~kg}$ of live weight (GMQ) with a gain of (GMQ) of $821.6 \mathrm{~g} /$ day for the Landrace.

For these animals, free wandering is usual and this exposes them to various contaminations. In reality, the control of pork meat, highly necessary to protect consumers is poorly conducted. Among various diseases transmitted by pigs, helminthiasis is predominant. The others mainly include Distomatosis caused by Fasciola hepatica, Hydatidosis caused by Echinococcus granulosus, and Cysticercosis caused by Taenia solium. These parasites concurrently promote diseases and reduce the economic value of the animals. The losses induced by these parasitoses in humans and animals are estimated at between US\$10 million and US\$19 million per year for Echinococcosis in Tunisia, and over one million Algerian dinars for Distomatosis [2]. In Africa, $10 \%$ of the global burden of food associated disease is caused by cysticercosis resulting from human-to-human contamination by eggs of Taenia solium [3]. Cysticercosis is due to the larvae of the Taenia solium [4]. Humans are the certain host of this tapeworm, but pigs are the intermediate host contaminated by eggs in human stools. The high prevalence of pig cysticercosis is usually associated with a higher prevalence of taeniasis in humans and a higher risk of human to human contamination by eggs, leading to human cysticercosis and epilepsy. Cysticercosis in pigs has thus a double incidence, both on public health and economic growth.

Over $25 \%$ of the total population of Côte d'Ivoire leaves in Abidjan. The quality control of the food supplied to the town is thus critical. However, quality controls are poorly done, and the only practical approach is to convince providers to increase the quality of their production. Unfortunately, in Côte d'Ivoire, the question of taeniasis and cysticercosis is almost unknown, and no data are available. This study aimed to create a detailed map of the pig population in regions surrounding Abidjan, including a typology of the farms to establish "home based" veterinary control. An exhaustive field survey was conducted in Dabou, Aboisso, and Agboville to describe farming practices. Blood samples were also 
collected in pigs to address questions about the seroprevalence of cysticercosis. This study was thus the first opportunity to provide preliminary data on porcine cysticercosis in this region.

\section{Methods}

\subsection{Area and population of the study}

The survey was conducted from June of 2016 to August 2017, in the administrative districts of Dabou, Agboville, and Aboisso, located in southern Côte d'Ivoire. These districts provide most of the animals routed to the central slaughterhouse of Abidjan. These are also the districts where the most contaminated meat (cysticercosis, echinococcosis, etc.) is condemned and eliminated. The National Study Bureau (BNET) submitted an exhaustive list of villages surrounding the three selected cities, and pigs' herds were analyzed for each village. Preliminary visits were conducted at each village to contact authorities and identify villages rearing pigs. The survey population consisted of hog producers who were questioned about: i) their family's profile and ii) the characteristics of their farms. A census of pig population was taken within the various localities which, were then listed accordingly.

\subsection{Epidemiological study}

Following the pig population's exhaustive investigation in the three districts, the number of pigs to be sampled for the serology analysis was calculated to give a $4 \%$ precision with $80 \%$ of power for an estimated cysticercosis prevalence of $50 \%$. The $5 \%$ extra effectiveness of pigs was added, which lead to a total of 600 pigs to investigate over the three districts. A random method was applied using a cumulative quota approach for the herds' sampling in the different villages. The number of pigs to be sampled in each district was calculated according to the total pig population's proportion. In total, the estimated sample size was 243,197, and 160 pigs, respectively, in Aboisso, Agboville, and Dabou . For each district, the number of pigs to be sampled in each village was calculated according to the proportion of the pigs' ratio registered to the district's total pigs. All the villages with more than ten pigs were considered for sampling. In each village, pigs were considered to belong to the same herd and were randomly sampled to constitute one generation of animals. After receiving the pig producers' informed consent, selected pigs over three months of age were blood sampled. GPS location of each herd was registered using the Garmin device. A specific questionnaire was administered for each herd and each animal of the distinct herd. Blood samples were kept in a cold chain at four ${ }^{\circ} \mathrm{C}$ until treatment at the laboratory.

\subsection{Cysticercosis serology}

Detection of antibodies against cysticercosis was conducted using the Tsang et al. glycosylated fraction of the cyst [5]. Sera were first used in ELISA ( $\mathrm{lgG})$, and positive ones were secondary analyzed using western blot (lgG). (Detailed protocol is available on www.protocols.iso). Negative controls used to define the threshold of positivity were serums from piglets originated from the industrial herds. For this study, positive serology for cysticercosis was defined as positive in ELISA and positive in Western Blot. At least 
two bands among P6-8, P12, P23-26, P39, P45 were used to define positive western blot [6]. P50-55 band was not considered during this study as it is believed to foster cross-reactivity with $T$ hydatigena, a pig tapeworm [7].

\subsection{Data analysis}

The data were entered into the Epidata 3.1 software and then analyzed using STATA version 11 software. Qualitative variables were compared with the Chi2 test or the Fisher exact test wherever appropriate. Quantitative variables were compared with the Kruskal-Wallis test. All the maps are computed in ArcView using "free of use" administrative maps generated by the CIGN of the Bureau National d'Etudes Techniques et de Développement(BNETD).

\section{Results}

\subsection{General profile of the breeders}

A total of 321 breeders were recorded, in Dabou (72, 22.4\%), in Aboisso (26, 8.1\%), and Agboville (223, 69.5\%) (Table I). They were located in 51 villages (9 in Dabou, 16 in Aboisso, and 26 in Agboville, Figure 1). Consequently, villages' range varied from zero to 35 , inducing a putative focus on diseases. Most producers were men $(84.7 \%, 96.1 \%$, and $87.9 \%$ of the breeders in the three regions, respectively). The family's average size varied from $6.4 \pm 3$ to $10.5 \pm$ nine persons per household (Table I). Surprisingly in Agboville and Dabou, the breeders were single men, respectively.26.9\% and $2.7 \%$. of

\subsection{Characteristics of the farms}

Out of 3,663 hogs registered, Agboville farms accounted for 2,537 heads (69.2\%), while Dabou and Aboisso accounted for 713 (19.4\%) and 413 (11.2\%), respectively. The livestock was more important in Agboville than in the other localities, but the average herd size was higher in Aboisso $(P=0.002)($ Table 1).

The composition of pig farms showed a high proportion $(P=0.000)$ of piglets $(60.2 \%$, Dabou $53.7 \%$, Aboisso 58.9\% and Agboville 62.3\%) compared to sow (29.3\%) and boar (10.5\%) (Table I). The Median number of pigs by breeding was 5 (3-10), 12 (8-20), 9 (4-16) in Dabou, Aboisso, and Agboville, respectively. This number was statistically lower in Aboisso $(P=0.001)$.

The livestock size increased slightly with the size of the farmer's household $(r=0.3, P=0.000)$. (Figure 2), irrelevant of the gender of the farmer $(P=0.16)$.

In Dabou, the smallest farm had 59 pigs and the biggest one, 353 pigs. Most of the animals were piglets (Table I), and sows were more frequent than boars. Half of the herds had no boars, and the sex ratio (boar/sow) varied with the district 1/2, 1/4, 1/3 at Dabou, Aboisso, and Agboville., respectively.

The main breed of pigs reared in these localities was the local one (81.3\%), especially in Agboville (95.2\%, $P=0.000$ ), which was representative of the traditional farming model. In parallel to these local breeds, 
mixed races were found in the three districts accounting for $16.2 \%$ of the animals (Table I). In Dabou, mixed-race was more prevalent $(P=0.000$, Table I). The median size of breeding was dependent on the pig race in Agboville $(P=0.042)$ but not so for the total of the three districts $(P=0.60)$. Likewise, there was no observed relationship between gender of the farmer and the race of the pig breaded $(P=0.67)$. In Dabou, barn lot was more prevalent $(P=0.000)$, whereas, in other localities (Aboisso, Agboville), almost all the farms practiced free range. Female breeders were more likely than males to practice permanent wandering $(69.2 \%$ vs. $51.1 \%, P=0.033)$ (Figure 2$)$.

\subsection{Seroprevalence of pig cysticercosis}

For the three districts, a total of 3,628 pigs was found, with 713 in Dabou, 378 in Aboisso, and 2,537 in Agboville, leading to sampling size of 197, 160, and 243 animals in these three districts, respectively. A total of 659 pigs were included, with 203 in Dabou, 271 in Agboville, 185 in Aboisso (Table II). Among these animals, 224 were positive with antibodies against cysticercosis in ELISA (37.9\%): $74(38.1 \%)$ in Dabou, 47 (17.6\%) in Agboville, and 103 (58.1\%) in Aboisso. Aboisso had the highest prevalence, with more than half of the animals contaminated $(p<0.05)$. Indeed, among Elisa positive serums, only 83 were positive with western blot. Thus, the final seroprevalence was $13.20 \%$ with de $20.7 \% ; 7.9 \% ; 13.1 \%$ in Dabou, Agboville, and Aboisso, respectively (Table II, significant difference $\mathrm{P}<0.001$ ). The prevalence of antibodies against cysticercosis varied from one herd to another (Figure 3) peaking, at more than $40 \%$ in some herds. The geographical association of herds with a high prevalence of cysticercosis could also be observed in some districts (Figure 3 ).

\section{Discussion}

According to local tradition, in the South of Côte d'Ivoire, pig rearing is mostly an artisanal production, which differs from one district to another. The larger number of herds was found in Agboville which registered numerous villages spread over $3,850 \mathrm{~km}^{2}$. In this district, animals are feed on household dumps. In Dabou, the low number of pigs can be explained by the fact that people mainly practice fishing. Furthermore, Dabou is closer to Abidjan, and breeding activities decrease drastically in proportion to the high economic and commercial activities. Similarly, in the Aboisso district, the low number of pigs recorded could be explained by the villagers' principal activity which is agriculture (cocoa, coffee, palm oil, and rubber [14]. In this region, pig farming is not recommended by tradition because pigs are known to destroy crops and spread filth throughout the village [15].

Nonetheless, the number of pigs registered during this study is far from the number of farmers and livestock registered by the Association of Pig Producers of Côte d'Ivoire [16]. This difference can be explained by the design of our study, focusing on traditional farms. The traditional breeding methods are mostly conducted on disordered course, which did not permit an accurate census of breeders and animals. Similarly, since May of 1996, the swine population is regularly affected by the African Swine fever epidemics (ASF), which deeply impacts the production of "modern" pigs ( $64 \%$ of decline) as well as 
traditional pigs (32\%) [17]. Further, the Ivorian pork industry is subjected to fierce competition from imported pork and other pig products derivative [16].

Unlike other countries, most of the breeders are men rather than women and children who mostly raise poultry. Animal rearing represent permanent savings to solve future problems [7-9-10-11]. However, this activity can also be a regular commercial activity for the family. This is in line with the increase in livestock size with the size of the farmer's household. Conversely, in the basin where groundnut is harvested, this activity seems to be dominated by women [9]. In these regions, women preparing traditional beers and alcohol with the grains sell the seeds to the farmers to feed their animals in compensation of piglets. This method allows them to rear small domestic livestock which are fed with the seeds [12-13].

Female pig producers are more likely than males to practice permanent wandering because men are traditionally not involved in household activities and food crops.

The high proportion of the young pigs is an indicator of the excellent prolificacy of sows, but it is still lower than in neighboring countries such as Senegal (range of 7.1) [18] or Cameroon (range of 12.4) [9]. According to the district, the proportion of boars remains low in the three districts with $15 \%, 13 \%$, and $8.7 \%$ of the herd. This could be explained by the quick turnaround of boars, which are sold and slaughtered during the holidays. This fact has also been observed in Senegal [19], Central Africa [20], and Benin [21]. For these authors, the low proportion of boars would indicate the traditional rearing pattern of local pigs. The boar/sow ratio decreases closer to Abidjan to 1/8 [16] and even 1/10 [8]. The short lifetime of boars can reduce the contamination of the pigs and consanguinity.

The high number of the local breed observed in this study is similar to Cameroon's data, where local breed accounted for $95 \%$ of the population [9], or from Madagascar [22]. In Côte d'Ivoire overall, the proportion of mixed breeds is higher in Dabou $(54,1 \%)$ than in the other districts. The same proportion is observed in Bangui (52\%) [9] due to stray farming systems where the projections are not controlled.

The predominant barn lot farms observed in Dabou belong to employees of industrial palm and rubber cooperatives. These cooperatives are at the origin of rearing in barns, as it is supposed to increase productivity, reduce damage caused by stray animals, reduce the spread of diseases, and avoid conflicts between farmers. [27]. In Côte d'Ivoire, for confinement farms, the breeding is controlled by the breeder. Boars used for this purpose are either borrowed from other farms or purchased [28]. The origin of boars is mostly unknown, including multiple crosses, which increases the risk for consanguinity [29]. Unlike Dabou, the other localities practice the permanent system. In this system, projections are uncontrolled, and increasing consanguinity is observed [29]. The farrowing is seldom executed in the enclosure, but rather in nature, next to the compound. This system is the cheapest and the easiest method for the farmers, however it exposes animals to massive infestations and various pathologies, leading to high mortality, slow growth, and low productivity [25]. 
The detection of anti-cysticercosis antibodies is indicative of the spread of Taenia solium in these districts. The practice of traditional animal husbandry increases contacts between the pigs and human feces. In fact, the population leaving in rural districts often defecate outdoors due to the lack of modern latrines. These practices significantly increase contacts between human feces and the animals. In the villages investigated, farms are mostly located close to the household dumps nearby latrines [30]. The highest seroprevalence was observed in Aboisso using the ELISA technic, which can be considered as relatively high according to Druet [31], who collected data all over sub-Saharan countries with prevalence ranging from 0.2 to $24 \%$. A similar prevalence of $38 \%$ was reported by Zoli [32] in the Ménoua region, using the same technic and by Nguekam [33] (21. 7\%). However, a lack of specificity was described for ELISA due to cross-reactivity with other helminths. [34].

The final seroprevalence obtained with Western Blot shows significant differences between localities. (Figure 1). However, in Abidjan's slaughterhouses, by visual inspections of the carcasses, this prevalence is higher than that reported by Geerts [35]. Visual inspection is much less sensitive than serology and highly dependent on the user's technical competence [36].

\section{Conclusion}

This study aimed to estimate the pig's population in three districts of the country's southern regions (Aboisso, Agboville, and Dabou) and characterize the breeding system practiced in these districts. The southern part of Cote d'Ivoire is the main supplier of pork for Abidjan. In this region, livestock is modest, and pig farming is conducted mainly by men. The rearing modes were mainly free wandering and rarely permanent confinement. These methods are associated with an overall moderate cysticercosis seroprevalence, which can peak to more than $40 \%$ in some villages. It is essential to control this disease in these villages to reduce its potential health impact. The control of cysticercosis in pigs is the first means of control to prevent the spread of the infection. It is important to educate the population about farming practices. Pigs should be confined in enclosures or in a site where they have no access to $t$ human feces and not be allowed to roam freely. The population should be sensitized about controlled hygienic practices such as building latrines far from livestock enclosures to prevent the diffusion of parasitic eggs into the environment. In addition, it is necessary to implement official meat inspection regulations to control this parasitosis. Similarly, the small sizes of the herds can be used as an opportunity to implement permanent confinement of pigs as a new practice, in particular in area where women are involved as they can use kitchen waste as valuable food for the livestock.

\section{Declarations}

\section{Abbreviations}

Not applicable

\section{Ethics approval and consent to participate}


The study obtained approval from and was supervised by the Ministry of Agriculture. Client-owned animals gave their informed consent for the study and supervised sampling of their herd.

\section{Consent for publication}

All the authors read the last version of the text and agreed for publication.

\section{Availability of data and materials}

Data are covered by administrative approval. They can be obtained from the authors through reasonable requests. They have no role in the design of the study, sample collection, analysis, and interpretation of data or in writing the manuscript

\section{Competing interests}

The authors declare no conflict of interest.

\section{Funding}

This work is supported by a grant from the PASRES program (Swiss Cooperation) and Pasteurlnnov program (Institute Pasteur, Paris).

\section{Authors' contributions}

KKE has conducted field and laboratory studies and drafted the manuscript, MKS supervised epidemiological protocol and analysis, and drafted the manuscript, BM supervised epidemiological protocol and participated in field studies participated in laboratory studies and standardized in vitro model,

MJ and NB conducted a serological investigation

KA standardized in vitro model and reviewed the manuscript, OAT, DAJ, and NKE reviewed the manuscript and participated in the design of the study RJ coordinated the project, conducted the statistical analysis, and wrote the manuscript All authors have read and approved the manuscript

\section{Acknowledgments}

We would like to extend our gratitude to the pigs'producers, the field investigators (ANADER and Veterinary Services) of Dabou, Aboisso, and Agboville for allowing us to lead the investigation. We also like to thank the entire EpiCysti team of IPCI for their technical support. We would like to thank Dr. Serge 
AGBO for his review of the document. We thank Dr Cataud Marius (IPCI), for his help to generate the maps.

\section{References}

[1] Miparh., Annuaire des statistiques des ressources animales et halieutiques Côte d'Ivoire, 2017, 42P.

[2] Bendiaf H., Contribution à l'Etude de la Distomatose de fasciola hepatica (Linn€, 1758): Aspects Parasitologique. et Sérologique. MÉmoire de Magister en Médecine Vétérinaire, Universite Mentouri de Constantine d'Algérie, $2011 ; 117$ pages

[3] WHO., Library Cataloguing-in-Publication Data WHO estimates of the global burden of foodborne diseases: foodborne diseas.,e burden epidemiology reference group 2007-2015; 265 P

[4] Geerts S., Zoli A., Willingham L., Brandt J., Dorny P., Preux P.M., Taenia solium cysticercosis in Africa: an under-recognised problem. In: Craig P., Pawlowski Z. (Eds.), Cestode zoonoses: echinococcosis and cysticercosis an emergent and global problem. eds., IOS Press, Amsterdam, 2002, pp395.

[5] Tsang V.C., Brand J.A., Boyer A.E., An enzyme-linked immunoelectrotransfer blot assay and glycoprotein antigens for diagnosing human cysticercosis (Taenia solium). The Journal of infectious diseases (1989) 159: 50-9.

[6] Michelet L., Le complexe taeniase/cysticercose, la phylogénie et l'évolution de Taeniasolium et la biologie moléculaire appliquée au diagnostic. Thèse de Doctorat de Sante publique et épidémiologie, Université de Limoges, France, 2010.

[7] Muro C1., Gomez-Puerta L.A2., Flecker R.H3., Gamboa R1., Barreto P.V1., Dorny P4., Tsang V.C.W5., Gilman R.H6., Gonzalez A.E2., Garcia H.H7,1., O'Neal S.E., For The Cysticercosis Working Group In Peru. Porcine Cysticercosis: Possible Cross-Reactivity of Taenia hydatigena to GP50 Antigen in the EnzymeLinked Immunoelectrotransfer Blot Assay. Am J Trop Med Hyg. (2017) doi: 10.4269/ajtmh.17-0378.

[8] Tra B., Filière porcine en Côte d'Ivoire, Production, propositions d'amélioration et perspectives de développement. Thèse de Médecine Vétérinaire, Ecole Inter Etats des Sciences et Medecine Vétérinaire de Dakar/ Sénégal,2009.

[9] Mopate L.Y., Koussou M.O., Nguertoum E.A., Ngo T.A.C., Lakouetene T., Awa D.N., Mal M.H.E., Caractéristiques et performances des élevages porcins urbains et périurbains des savanes d'Afrique centrale : cas des villes de Garoua, Pala et Bangui. Savanes africainesen développement. Montpellier : CIRAD, 2010, 9p.

[10] Rabeniala R., Raoliarivelo L., Masezamana H., Randriamalala R., Gestion de pâturage pour petits ruminants (ovins et caprins) dans une zone semi-aride du district de Toliara II. Rapport final, DERAD, Eastern and Southern Africa Partnership Programm, Antananarivo, 2009, $50 \mathrm{p}$ 
[11] Oussou., Rôle des éleveurs de caprins dans l'émergence des maladies caprines (Capra hircus, schaller, 1977) dans la localité de Beoumi (Côte d'Ivoire). J. Appl. Biosciences (2017).

[12] Mopate L.Y., Dynamique des élevages porcins et amélioration de la production en zones urbaine et périurbaine de N'Djaména (Tchad). Thèse de Doctorat Unique, Gestion intégrée des ressources naturelles (GIRN), option, Productions animales, Université polytechnique de Bobo-Dioulasso (UPB), Burkina Faso,2008.

[13] Beck., T, Gender mainstreaming in agriculture and rural development, A reference manual for governments and other stakeholders, Commonwealth, 2001

[14] Koua A., Situation de la production de café en côte d'ivoire,cas du département d'Aboisso, état des lieux et perspectives. Mémoire d'Ingénieur Agronome, option agroéconomie, École Supérieure d'Agronomie de Yamoussoukro,2007.

[15] Mavouenzela D., Anglade K., Dourou B,Foutou G ., Bamona R., Étude sur la filière porc dans le Département de Pointe Noire, Congo,2014, 43P.

[16] Apporci., Les difficultés de la filière porcine ivoirienne face aux importations massives de produits porcins : Rapport. - Abidjan : APPORCI,2004, 5 p.

[17] Miparh., Programme d'appui à la redynamisation de la filière porcine. - Abidjan : SIVAC,2006,22 p.

[18] Sambou G., Analyse des impacts de la décharge de Mbeubeus (Dakar) sur les élevages porcins environnants. Thèse de Médecine Vétérinaire, Ecole Inter Etats des Sciences et Medecine Vétérinaire de Dakar/ Sénégal,2008.

[19] Missohou A., Niang M., Foucher H., Dieye P.N., Les systèmes d'élevage porcin en Basse Casamance (Sénégal). Cahiers Agricultures (2001)10 (6) : 405-408.

[20] Abdallah E., Élevage porcin en région périurbaine de Bangui/Centrafrique. Thèse de Médecine Vétérinaire, Ecole Inter Etats des Sciences et Medecine Vétérinaire de Dakar/ Sénégal,1997.

[21] Deka E., Chrysostome C., Nonfon W.R., Amélioration de la productivité du porc local au sud Bénin : rapport II Atelier de restitution des résultats de recherche sur le porc local aux différents acteurs de la filière porc. - UAC : FSA/CRDPL,1998, $62 \mathrm{p}$.

[22] Humbert C., Etude épidémiologique de la Peste Porcine Africaine dans la region de Marovoay (Madagascar). Mémoire de Certificat d'Etude Approfondie Vétérinaire, Pathologies animales en région chaude, ENV Toulouse,2006.

[23] Serres H., Précis d'élevage du porc en zone tropicale. - Ministère Français de la Coopération et du Développement. - Paris : manuel et précis d'élevage,1989, 331 p. 
[24] Buldgen A.,Piraux M.,Dieng A.,Schmit G., Compere R., Les élevages de porcs traditionnels du bassin arachidier sénégalais. Revue Mondiale de Zootechnie (1994). 80/81, 3-4 : 63-70.

[25] Holnes D.H., Le porc. Paris : Maison neuve et Larose ; ACCT- CTA,1994,217 p.

[26] Lukusa B.D., Amélioration de la pratique d'élevage de porcs dans les milieux urbains et périurbains de la ville de Kinshasa. Mémoire de Diplôme d'Études Spécialisées en Gestion des Ressources Animales et Végétales en Milieux Tropicaux, Faculté Universitaire des Sciences Agronomiques de Gembloux, 2005.

[27] Youssao A.K.I., Koutinhouin G.B., Kpodekon T.M., Bonou A.G., Adjakpa A., Dotcho C.D.G., Atodjinou F.T.R., Production porcine et ressources génétiques locales en zone périurbaine de Cotonou et d'AbomeyCalavi au Bénin. Revue d'Élevage et de Médecine vétérinaire des Pays tropicaux (2008) 61: 235-243.

[28] Nonfon W.R., Amélioration de sa productivité par l'alimentation. Thèse de Doctorat en Sciences agronomiques et Ingénierie biologique, Faculté Universitaire des Sciences Agronomiques de Gembloux, Belgique,2005.

[29] Agbokounou A.M., Étude des besoins énergétiques et protéiques du porc local béninois en phase de démarrage croissance. Mémoire de DEA, Sciences agronomiques et Ingénierie biologique, Orientation élevage, Faculté Universitaire des Sciences Agronomiques de Gembloux, Belgique,2001.

[30] Rasamoelina et al., La Cysticercose porcine à travers le langueyage dans le district de Tsiroanomandidy. Thèse de Médecine Vétérinaire, soutenue à Antananarivo Madagascar $47 \mathrm{P}$

[31] Druet C. M., Ramanankandrasana B., Bisser S., Dongmo L., Avode G., Nzisabira L., Taenia solium Cysticercosis in Africa. Taenia Solium Cysticercosis: From Basic to Clinical Science (2002)129.

[32] Zoli, A., Geerts S., Vervoort T., An important focus of human and porcine cysticercosis in WestCameroun. In "Current topics in Veterinary Medicine and Animal Science." (Helminth Zoonoses) Ed. Geerts et al.,1987, p. 85-91.

[33] Nguekam, J.P., La Cysticercose Porcine dans les Departements de la Mifi et des Bamboutos. Master of Science Thesis, Institut de la Médicine Tropicale, Anvers-Belgique,1998.

[34] Mandal J., Singhi P.D., Khandelwal N., Malla N., Evaluation of ELISA and dot blot for the serodiagnosis of neurocysticercosis in children found to have single or multiple enhancing lesions in computerized tomographic scans of the brain. Annals of tropical medicine and parasitology (2006) 100: $39-48$.

[35] Mishra G.S., N'Depo A.E., Les cysticerques des animaux abattus a l'abattoir de Port-Bouet (Abidjan), (Cote d'Ivoire). Rev Elev Med vet Pays trop. (1978) .31(4), 431-436.

[36] Goussanou S., Kpodekon T., Saegerman C., Azagoun E., Youssao A., Farougou S., Praet N., Gabriël S., Dorny P., Korsak Koulagenko N., Spatial distribution and risks factors of porcine cysticercosis in southern 
Benin based meat inspection records. International Research Journal of Microbiology (2013) 4 (8): 188196.

\section{Tables}

Table I. Characteristics of the pig producers and of the herds in the three districts of Dabou, Aboisso, and Agboville

\begin{tabular}{|c|c|c|c|c|c|c|}
\hline & & $\begin{array}{l}\text { Dabou } \\
\text { n (\%) }\end{array}$ & $\begin{array}{l}\text { Aboisso } \\
\text { n (\%) }\end{array}$ & $\begin{array}{l}\text { Agboville } \\
\text { n (\%) }\end{array}$ & $\begin{array}{l}\text { Total } \\
\text { n (\%) }\end{array}$ & $\begin{array}{l}\text { P } \\
\text { (Chi2 } \\
\text { test) }\end{array}$ \\
\hline \multirow[t]{3}{*}{ Pig producers } & Male & $61(84.7)$ & $25(96.1)$ & 196 (87.9) & $282(87.8)$ & $0.33^{*}$ \\
\hline & Female & $11(15.3)$ & $1(3.9)$ & $27(12.1)$ & $39(12.2)$ & \\
\hline & Total & 72 & 26 & 223 & 321 & \\
\hline \multicolumn{2}{|c|}{ 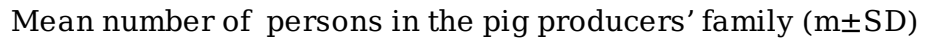 } & $6.5 \pm 3.2$ & $10.5 \pm 9.5$ & $7.8 \pm 5.6$ & $7.7 \pm 5.7$ & $0.16^{* *}$ \\
\hline \multicolumn{2}{|c|}{$\begin{array}{l}\text { The median number of pigs by breeding [Median (Interquartile } \\
\text { range)] }\end{array}$} & $5(3-10)$ & $12(8-20)$ & $9(4-16)$ & $11.4 \pm 10.6$ & $0.001 * *$ \\
\hline \multirow[t]{4}{*}{ Livestock structure } & boars & $107(15)$ & $54(13.1)$ & $222(8.7)$ & $383(10.5)$ & \\
\hline & sow & $\begin{array}{l}223 \\
(31.3)\end{array}$ & $\begin{array}{l}117 \\
(28.3)\end{array}$ & 733 (28.9) & $\begin{array}{l}1073 \\
(29.3)\end{array}$ & 0.000 \\
\hline & Young pig & $\begin{array}{l}383 \\
(53.7)\end{array}$ & $\begin{array}{l}242 \\
(58.6)\end{array}$ & $\begin{array}{l}1582 \\
(62.3)\end{array}$ & $\begin{array}{l}2207 \\
(60.2)\end{array}$ & \\
\hline & Ratio b:s & $1: 2.0$ & $1: 4.1$ & $1: 3.3$ & $1: 3.2$ & \\
\hline \multirow[t]{3}{*}{ Race } & Locale & $\begin{array}{l}322 \\
(45.2)\end{array}$ & $\begin{array}{l}217 \\
(52.5)\end{array}$ & $\begin{array}{l}2415 \\
(95.2)\end{array}$ & $\begin{array}{l}2954 \\
(80.6)\end{array}$ & \\
\hline & Metis & $\begin{array}{l}386 \\
(54.1)\end{array}$ & $88(21.3)$ & $93(3.7)$ & $567(15.5)$ & 0.000 \\
\hline & Other & $5(0.7)$ & $\begin{array}{l}108 \\
(26.2)\end{array}$ & $29(1.1)$ & $142(3.9)$ & \\
\hline \multirow[t]{2}{*}{ Breeding mode } & Enclosure breeding & $45(62.5)$ & $21(80.8)$ & $84(37.7)$ & $150(46.7)$ & \\
\hline & free-range & $27(37.5)$ & $5(19.2)$ & 139 (62.3) & $171(53.3)$ & 0.000 \\
\hline
\end{tabular}

* Fisher test exact; ** Kruskal Wallis test

Other (not identified) b (boar) s (sow)

Table II: Seroprevalence of anti-cysticercosis antibodies in the herds of the three districts of Dabou, Agboville, Aboisso 


\begin{tabular}{llll}
\hline District & Aboisso & Dabou & Agboville \\
\hline N of villages & 10 & 8 & 13 \\
N of farms/herds & 24 & 33 & 59 \\
N total of animals & 387 & 535 & 1614 \\
N of animal sampled & 177 & 194 & 267 \\
N of Positive animals ELISA (\%) & $103(58.1)$ & $74(38.1)$ & $47(17.6)$ \\
N of positive animals WB (\%) & $21(11.9)$ & $37(19.0)$ & $20(7.4)$ \\
N of positive villages (\%) & $7(70)$ & $8(100)$ & $5(23.7)$ \\
N of positive herds n (\%) & $10(41.6)$ & $22(66.0)$ & $14(23.7)$ \\
\hline Prevalence maxi by herd & 33 & 100 & 75 \\
Prevalence min by herd & 0 & 0 & 0 \\
Mean prevalence by herd & 11.8 & 19.0 & 7.4 \\
\hline
\end{tabular}

$\mathrm{N}$ : Number, WB : Western

\section{Figures}




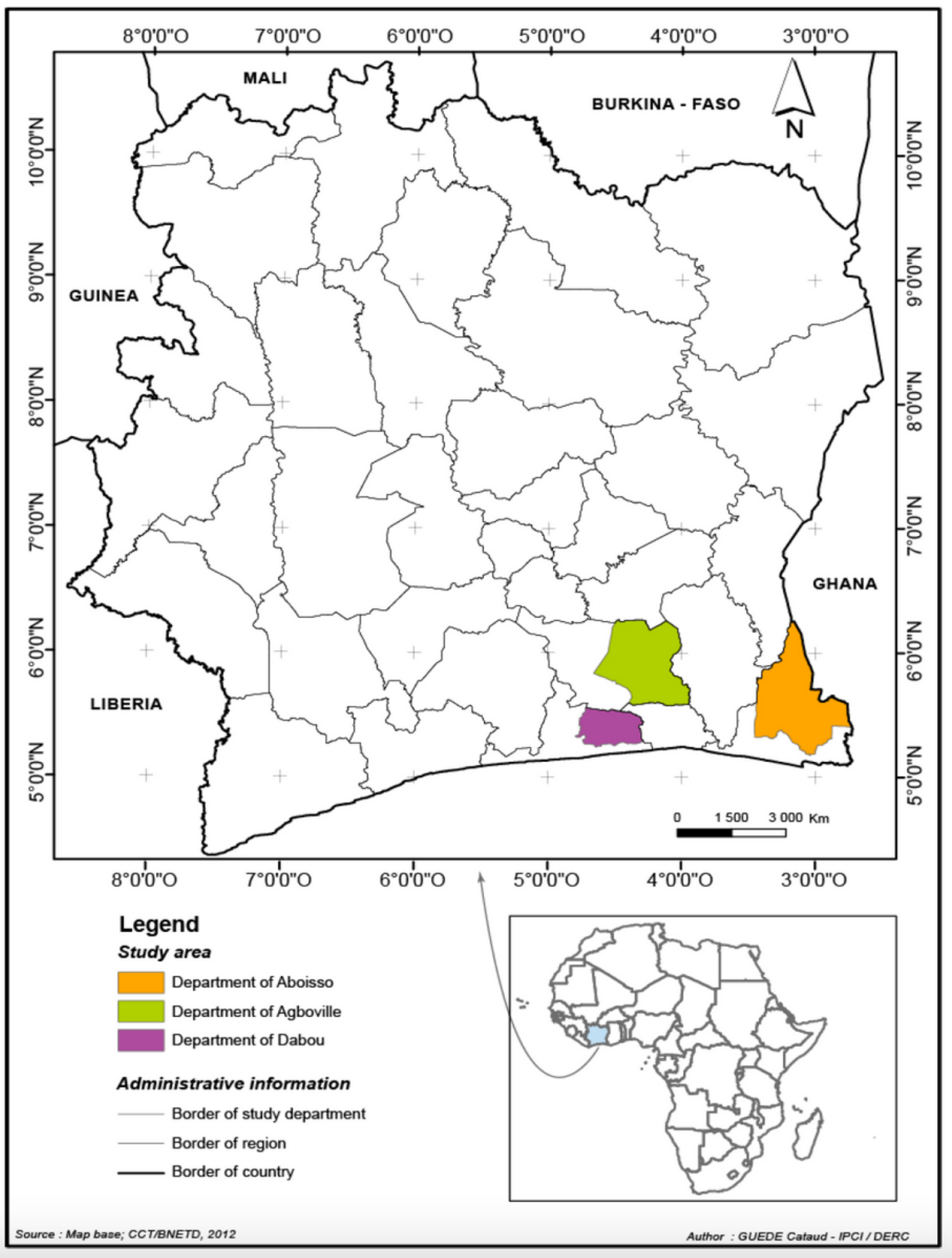

Figure 1

Localization of the study areas 


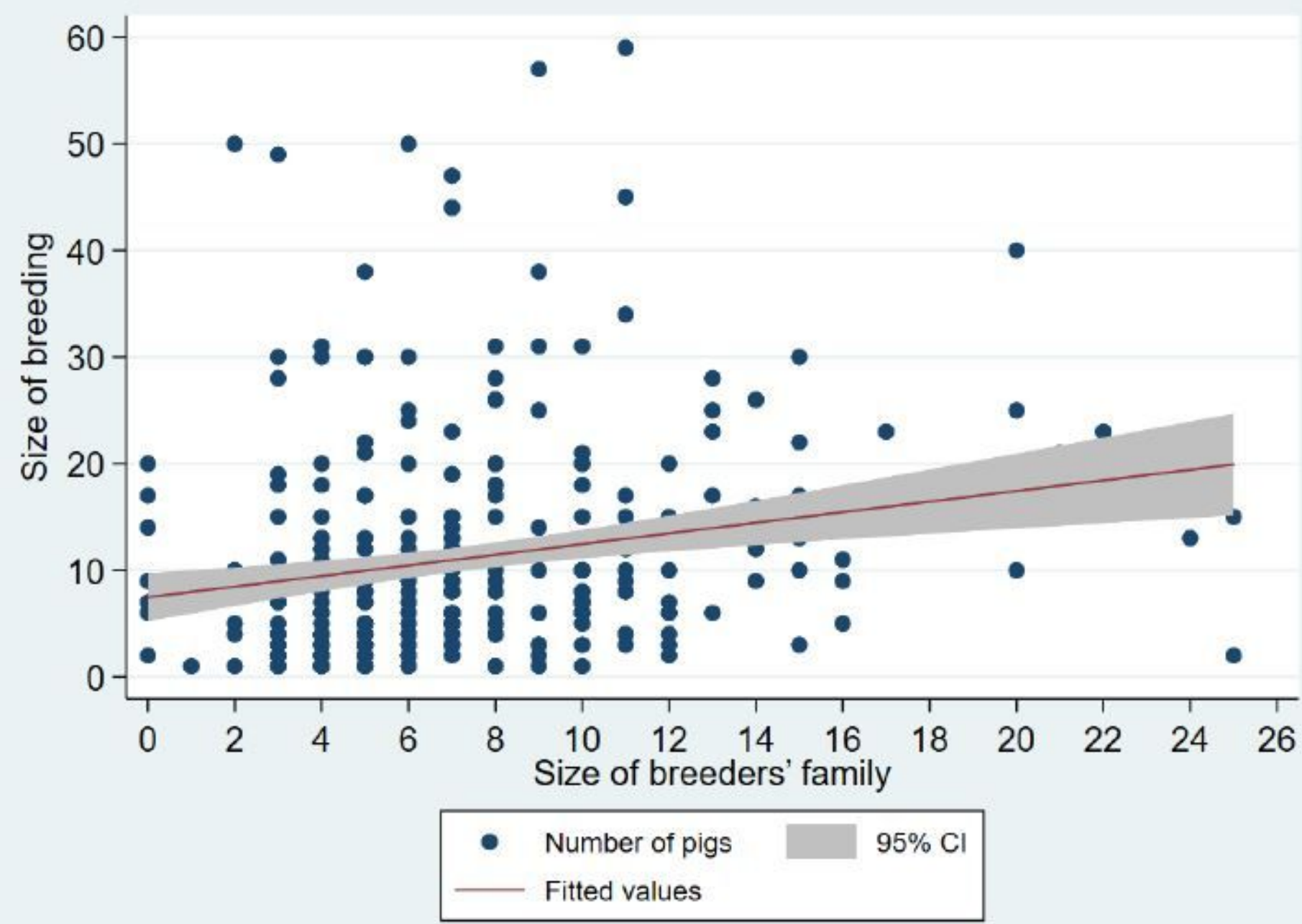

Figure 2

Correlation between the size of the farmer's household and the size of the livestock herd 


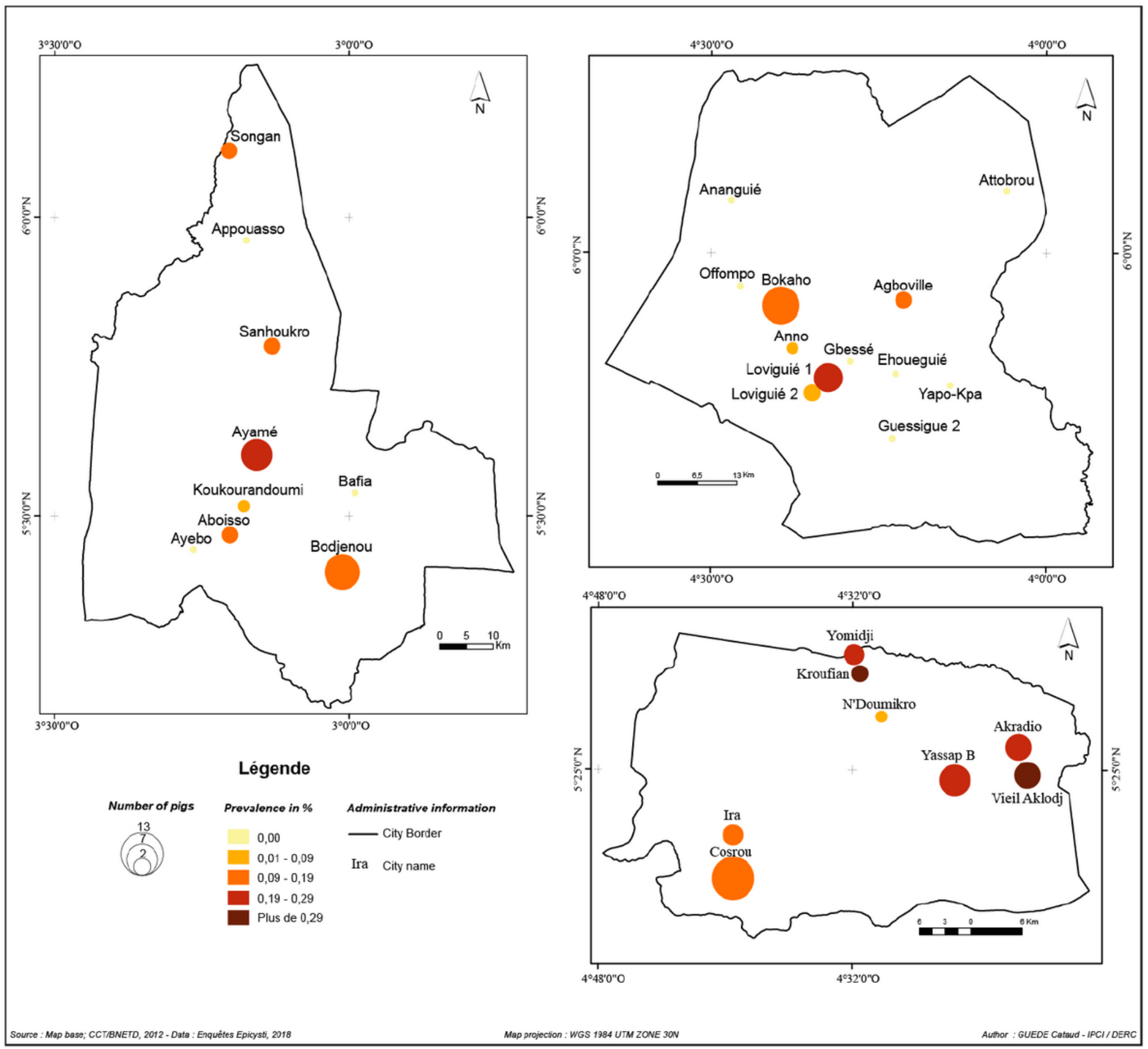

Figure 3

Prevalence of cysticercosis in the districts of Dabou, Agboville, and Aboisso A/ Dabou, B/ Agboville, C/ Aboisso. The size of the circles indicates the number of pigs investigated; the color of the circle indicated seroprevalence of ant-cysticercosis antibodies

\section{Supplementary Files}

This is a list of supplementary files associated with this preprint. Click to download.

- ECart1suppldata.doc 